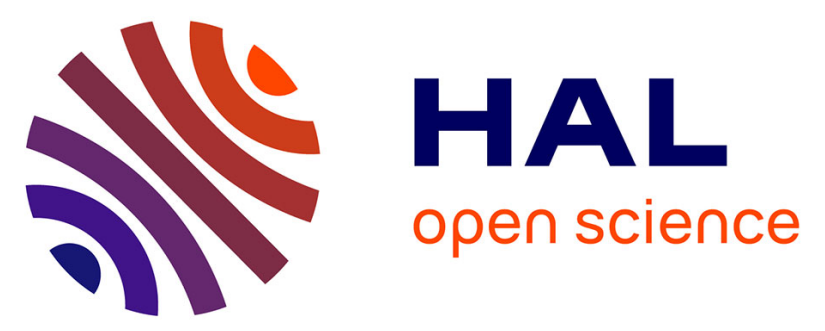

\title{
Modification of activities of the ruminal ecosystem and its bacterial and protozoan composition during repeated dietary changes in cows
}

Valérie Monteils, Mikael Rey, Mathieu Silberberg, Laurent L. Cauquil, Sylvie Combes

\section{To cite this version:}

Valérie Monteils, Mikael Rey, Mathieu Silberberg, Laurent L. Cauquil, Sylvie Combes. Modification of activities of the ruminal ecosystem and its bacterial and protozoan composition during repeated dietary changes in cows. Journal of Animal Science, 2012, 90 (12), pp.4431-4440. 10.2527/jas.20114321. hal-02642559

\section{HAL Id: hal-02642559 \\ https://hal.inrae.fr/hal-02642559}

Submitted on 28 May 2020

HAL is a multi-disciplinary open access archive for the deposit and dissemination of scientific research documents, whether they are published or not. The documents may come from teaching and research institutions in France or abroad, or from public or private research centers.
L'archive ouverte pluridisciplinaire HAL, est destinée au dépôt et à la diffusion de documents scientifiques de niveau recherche, publiés ou non, émanant des établissements d'enseignement et de recherche français ou étrangers, des laboratoires publics ou privés. 


\section{JOURNAL OF ANIMAL SCIENCE}

The Premier Journal and Leading Source of New Knowledge and Perspective in Animal Science

\section{Modification of activities of the ruminal ecosystem and its bacterial and protozoan composition during repeated dietary changes in cows \\ V. Monteils, M. Rey, M. Silberberg, L. Cauquil and S. Combes}

J ANIM SCI 2012, 90:4431-4440.

doi: 10.2527/jas.2011-4321 originally published online September 5, 2012

The online version of this article, along with updated information and services, is located on the World Wide Web at:

http://www.journalofanimalscience.org/content/90/12/4431 


\title{
Modification of activities of the ruminal ecosystem and its bacterial and protozoan composition during repeated dietary changes in $\operatorname{cows}^{1}$
}

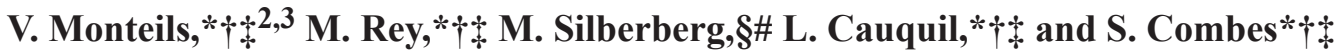 \\ *Université de Toulouse, INPT-ENSAT, UMR1289 Tissus Animaux Nutrition Digestion Ecosystème et Métabolisme, \\ F-31326 Castanet-Tolosan, France; †INRA, UMR1289, Tissus Animaux Nutrition Digestion Ecosystème et Métabolisme, \\ F-31326 Castanet-Tolosan, France; †Université de Toulouse, INPT-ENVT, UMR1289 Tissus Animaux Nutrition Digestion \\ Ecosystème et Métabolisme, F-31076 Toulouse, France; §INRA, UMR1213 Herbivores, F-63122 Saint-Genès-Champan- \\ elle, France; and \#Clermont Université, VetAgro Sup, UMR Herbivores, BP 10448, F-63000, Clermont-Ferrand, France
}

\begin{abstract}
Dietary change alters the ruminal ecosystem and can be regarded as a disturbance. Studying the response to a disturbance can help us understand the behavior of the ecosystem. Our work is concerned with the response of the ruminal ecosystem (composition and activities) during the application of repeated dietary disturbances to 6 dry Holstein cows. For 2 mo, the cows received a hay-based diet [experimental period (EP) 0], followed by $3 \mathrm{EP}$ of successive changes (EP 1, 2, and 3) comprised of 2 parts: the first ( $10 \mathrm{~d})$ with a corn silagebased diet and the second ( $25 \mathrm{~d})$ with a hay-based diet. The measurements and samplings were done on the last days of EP 0 and of each part of EP 1 through 3, with the results of EP 0 used as covariables in the statistical models. The physicochemical measurements $(\mathrm{pH}$ and redox potential) and the fermentation variables (VFA, ammonia) were determined hourly between the morning and evening meals $(n=8$ measurements/d). Samples of ruminal contents were taken $3 \mathrm{~h}$ after the morning meal to determine enzymatic activity [amylase, carboxymethyl cellulase (CMCase), and xylanase], to count the main protozoan genera and to quantify the bacteria by quantitative PCR, and to determine its structure by the capillary electrophoresis single-strand conforma-
\end{abstract}

tion polymorphism process. The $\mathrm{pH}$ fell for the corn silage-based diet with the EP $(P<0.05)$ but not for the hay-based diet. The VFA concentration decreased for both diets with the EP $(P<0.001)$, with the primary changes in acetate and propionate. The ammonia concentration increased for the corn silage-based diet with the EP $(P<0.05)$, whereas for the hay-based diet the highest value was observed for EP $2(P<0.05)$. The total quantity of bacteria decreased between EP 1 and $3(P<0.05)$ for both diets. The structure of the bacterial community was not affected by the disturbances for the corn silage-based diet, whereas for the hay-based diet large differences were evident between EP 1 and 3 $(P<0.05)$ and 2 and $3(P<0.01)$. The number of protozoa increased over the EP, with a more marked effect for the corn silage-based diet (diet $\times$ EP interaction, $P<0.05)$. The specific amylase, CMCase, and xylanase activities decreased over the EP for both diets $(P<$ $0.05)$. The dietary changes applied in our experiment involved strong modifications of the ruminal ecosystem and alterations of ruminal fermentation and enzymatic activities. These alterations were reinforced with the repetition of the dietary changes.

Key words: bacteria, cow, dietary disturbance, fermentation, protozoa, ruminal ecosystem

\section{INTRODUCTION}

\footnotetext{
${ }^{1}$ The authors thank the whole team who worked on this study during the experiments and by providing technical assistance in the laboratory. The Centre de Ressources Genotypage Sequençage platform of Toulouse, France, is acknowledged for technical assistance.

${ }^{2}$ Present address: VetAgro Sup, F-63370 Lempdes, France.

${ }^{3}$ Corresponding author: valerie.monteils@vetagro-sup.fr

Received June 1, 2011.

Accepted August 15, 2012.
}

A change in diet constitutes a disturbance of the ruminal ecosystem. The disturbance caused is associated with environmental changes for the microorganisms (e.g., nutrient availability, $\mathrm{pH}$, digesta flow). Faced with a disturbance, the microbial composition might be resistant or altered with or without the capacity to 
return to the initial state (Allison and Martiny, 2008). Several hours after a dietary change, the composition of the bacterial community is modified (Tajima et al., 2000, 2001), together with the physicochemical and fermentation measurements (Goad et al., 1998). Several days after, the ruminal ecosystem can exhibit a new state of equilibrium of fermentation measurements (Michelland et al., 2011).

One way of studying the ecosystem is to study its response to a disturbance. For digestive ecosystems, the most frequent disturbance is a change of diet. In the course of their lives, farm animals often experience dietary disturbances at critical periods, such as weaning, calving, dietary changes, turnout into pasture, etc. It also has been shown that the response of the ruminal ecosystem to a dietary disturbance depends on the initial conditions. For example, the decrease in ruminal $\mathrm{pH}$ after an acidogenic challenge was shown to depend on the nature of the diet ingested before the challenge and on the initial pH (Dohme et al., 2008). A disturbance could therefore provoke a different response in an animal depending on the number of times the animal has experienced it in the course of its life (i.e., on its history). All these considerations led us to hypothesize that dietary disturbances alter the ruminal microorganism composition, the fermentation and physicochemical measurements, and the main enzymatic activities and that the repetition of these disturbances exacerbates the alterations. The main novelty of this study was the repetition of dietary changes with a medium-term approach associated and a detailed characterization of the ruminal responses.

\section{MATERIALS AND METHODS}

All animal housing and handling procedures were cared for in accordance with the guidelines for animal research of the French Ministry of Agriculture (France, 1988).

\section{Animals, Diets, and Experimental Design}

Six Holstein cows were fitted with ruminal cannula (number 3 C, Bar Diamond, Parma, ID) 1 yr before the trial. The cows were neither gestating nor lactating throughout the trial. The animals were housed in individual $1.2 \times 2.2$ $m$ pens of the experimental unit of UMR 1289 TANDEM (Poucharramet, France). At the beginning of the study, the mean BW of cows was $640 \pm 78 \mathrm{~kg}$.

The experimental design is depicted in Figure 1. There was an experimental period (EP) of 2 mo at the start of the trial (EP 0), during which the animals received a hay-based diet. Thereafter, 3 successive EP (EP 1, 2, and 3) constituted the remainder of the trial. Each of these 3 EP consisted of 2 parts: one period $(10 \mathrm{~d})$ when the animals received $8.5 \mathrm{~kg} \mathrm{DM} / \mathrm{d}$ of a corn silage-based diet (Table 1) and a

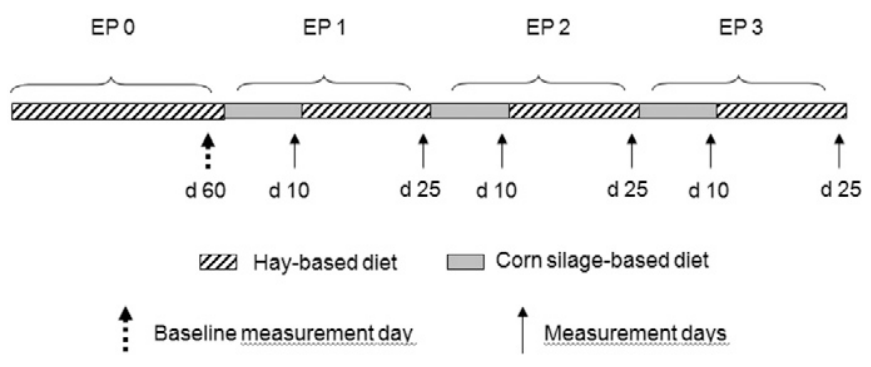

Figure 1. Experimental design of the trial. $\mathrm{EP}=$ experimental period. For each data point and for each of the 6 cows: 8 observations were done for $\mathrm{pH}$, redox potential, VFA and ammonia; and 1 observation was done for enzymatic activities, protozoan count, bacteria quantification and structure

second period $(25 \mathrm{~d})$ when they received $9.5 \mathrm{~kg} \mathrm{DM} / \mathrm{d}$ of the hay-based diet. The period of $10 \mathrm{~d}$ (corn silage-based diet) was thus considered as a disturbance period. A longer period ( $25 \mathrm{~d}$, hay-based diet) was then chosen to allow the ruminal ecosystem to reach a novel equilibrium or to return to the previous state. This last period could also be considered as a disturbance period, taking into account the dietary change compared with the previous period. The length of both periods allowed time for adjustment after each dietary change and an approach of the medium-term effect of dietary changes. Indeed, the length of the hay-based diet period was longer than the corn silage-based diet period in part to take into account the slower digesta flow with the hay-based diet and the associated slower turnover of ruminal contents, as reported by Faichney (1995).

Throughout the experiment, the cows were fed twice daily at 0900 and $1700 \mathrm{~h}$ in equal proportions with total mixed rations and with free access to fresh water. The composition of both diets met the recommended allowances of the animals (Jarrige, 1989) throughout the trial. The ani-

Table 1. Ingredient composition of the experimental diets fed to cows on corn silage- and hay-based diets (DM basis)

\begin{tabular}{lcc}
\hline \hline & \multicolumn{2}{c}{ Diet } \\
\cline { 2 - 3 } Item & Corn silage & Hay \\
\hline Ingredient, \% DM & - & 90.4 \\
$\quad$ Hay & 8.6 & 7.5 \\
Soybean meal & 37.6 & - \\
Corn silage & 25.5 & - \\
Wheat meal & 25.4 & - \\
Cracked corn & 2.9 & 2.1 \\
Minerals ${ }^{1}$ & & \\
Chemical composition & 67.4 & 91.7 \\
DM, \% & 94.3 & 92.9 \\
OM, \% DM & 21.3 & 25.8 \\
NDF, \% DM & 13.0 & 10.8 \\
CP, \% DM & 38.3 & 0.2 \\
Starch, \% DM & 1.58 & 1.12 \\
NE, Mcal/kg DM & & \\
\hline
\end{tabular}

${ }^{1}$ Contents (per kg of premix, DM basis): $90 \mathrm{~g} \mathrm{P}, 90 \mathrm{~g} \mathrm{Ca}, 100 \mathrm{~g} \mathrm{Mg}, 18 \mathrm{~g}$ $\mathrm{Na}, 8 \mathrm{~g} \mathrm{Zn,} 4$ g Mn, $120 \mathrm{mg} \mathrm{I}, 100 \mathrm{mg} \mathrm{Co}, 30 \mathrm{mg} \mathrm{Se}, 1.6 \mathrm{~g} \mathrm{Cu}, 800,000 \mathrm{IU}$ vitamin A, 200,000 IU vitamin D3, $10 \mathrm{~g}$ vitamin E, $10 \mathrm{mg}$ b carotene, $150 \mathrm{mg}$ vitamin $\mathrm{B} 1$, and 2,000 $\mathrm{mg}$ vitamin $\mathrm{C}$. 
mals were fed at $80 \%$ of their feed intake capacity according to Jarrige (1989). Individual intakes were measured daily by weighing the orts before the next meal. Dietary changes were made without any dietary transition so as to provoke a disturbance. The 6 dietary changes made during this study were all regarded as possible disturbances, both for the switch from the corn silage-based diet to the haybased diet and vice versa.

\section{Samplings and Measurements}

All samplings and measurements were made in the ventral sac of the rumen on the last day of EP 0 and of each part (the corn silage- and hay-based diets) of EP 1, 2, and 3 (Figure 1). The sampling times were retained to characterize the ruminal measurements after a time for adjustment to each disturbance, which was defined according to the dietary treatment as explained in the previous section.

The $\mathrm{pH}$ and the redox potential were measured with the ex vivo anaerobic method developed by Marden et al. (2005) and adapted by Julien et al. (2010). The device allowed for continuous sampling of ruminal fluid in anaerobic conditions while maintaining the ruminal temperature and mixing. Each hour from the morning (T0) to the evening feeding (T8), $\mathrm{pH}$ and redox potential values were recorded with a digital $\mathrm{pH}$ meter (model 713; Metrohm, Herisau, Switzerland), a glass $\mathrm{pH}$ electrode (combined with $\mathrm{Ag}-\mathrm{AgCl}$ reference; Metrohm), a redox potential platinum electrode $(\mathrm{Ag} / \mathrm{AgCl}$ as reference; Metrohm), and a thermoelectrode (Pt100; Metrohm). The redox potential data were corrected by adding the potential of the reference hydrogen electrode (i.e., +199 $\mathrm{mV}$; Nordstrom, 1977). During each sampling, approximately $500 \mathrm{~mL}$ of ruminal contents were filtered through a $250-\mu \mathrm{m}$ sieve. Three aliquots of the liquid fraction obtained $(8 \mathrm{~mL})$ were stored after adding $1 \mathrm{~mL}$ of mercuric chloride $(2 \% \mathrm{wt} / \mathrm{vol})$ and were immediately frozen at $-20^{\circ} \mathrm{C}$ until VFA, $\mathrm{NH}_{3}$, and lactic acid analyses.

To study the microbial community, an additional sample $(1 \mathrm{~L})$ of the ventral ruminal contents was collected on the same day $3 \mathrm{~h}$ after morning feeding. Filtration through a 1.6-mm metal sieve was done to make the sampling more homogeneous. Filtration through a 1.6-mm sieve was previously used to study the bacterial community structure and bacterial activity in ruminal contents (Michelland et al., 2009b; Privé et al., 2010; Monteils et al., 2011). The samples were preserved at $-80^{\circ} \mathrm{C}$ before DNA extraction and treatment. To study the protozoal community, $1 \mathrm{~mL}$ of ruminal fluid (ruminal content filtered through a $250-\mu \mathrm{m}$ sieve) was added to $1 \mathrm{~mL}$ of MFS solution (3.5\% formaldehyde, $0.14 \mathrm{M} \mathrm{NaCl}, 0.92 \mathrm{~m} M$ methyl green) and stored away from light at room temperature until protozoa were enumerated.
The enzymatic activities were measured from 250 $\mathrm{mL}$ of ruminal contents sampled $3 \mathrm{~h}$ after the morning meal (same sample as for the microbial community determination). The microbial populations and solid and liquid fractions were isolated using the method of Martin et al. (1993). A 50-g aliquot of the total contents was mixed with $25 \mathrm{~mL}$ of $0.025 \mathrm{M}$ 2-(N-morpholino) ethane-sulphonic acid (MES) buffer at pH 6.5 and stored at $4^{\circ} \mathrm{C}$ to determine the enzymatic activities of the total fraction. The rest of the sample was filtered through $250-\mu \mathrm{m}$ mesh nylon cloth. A 40-mL aliquot of the liquid fraction collected was used to determine the enzymatic activities of the liquid rumen fraction. Part of the residue obtained after filtration $(70 \mathrm{~g})$ was washed for 5 min with agitation in an anaerobic saline solution kept at $39^{\circ} \mathrm{C}(\mathrm{pH} 6.5 ; 5 \mathrm{~mL} / \mathrm{g})$ to eliminate the nonadhering microbial population according to Martin et al. (1993). After washing, the sample was filtered through a $100-\mu \mathrm{m}$ mesh nylon cloth. The solid fraction was sampled $(5 \mathrm{~g})$ and suspended in $25 \mathrm{~mL}$ of MES buffer solution kept at $4^{\circ} \mathrm{C}$ to determine the enzymatic activity associated with the solid rumen fraction. All samples were immediately stored at $-80^{\circ} \mathrm{C}$ until the enzymes were extracted. All withdrawn samples represented a maximum of $5 \mathrm{~L} / \mathrm{d}$ for each cow (approximately 5\% of the ruminal contents), which was considered a quantity that did not disturb ruminal function.

\section{Analyses}

Quantification of VFA was performed by automated gas chromatography (5890 Series II with a flame ionization detector, Hewlett-Packard, Avondale, PA) according to Playne (1985). Ammonia concentration was determined with a colorimetric method by a continuous flow analyzer (SAN++, Skalar, Norcross, GA) as previously described by Krom (1980). Total lactate (d1lactate) was determined using a commercial kit (Boehringer Mannheim/R-Biopharm, St Didier au Mont d'Or, France). For DNA extraction, PCR amplification and the capillary electrophoresis single-strand conformation polymorphism (CE-SSCP) processes were performed as described by Michelland et al. (2009b) for individual samples of ruminal contents. Total genomic DNA from approximately $0.2 \mathrm{~g}$ of sample was extracted and purified with a QIAamp DNA Stool Mini kit (Qiagen Ltd, West Sussex, England) according to the manufacturer's instructions after thermal (from liquid $\mathrm{N}$ to $95^{\circ} \mathrm{C}$ ) and mechanical lyses (bead beating using $400 \mathrm{mg}$ of 0.1 $\mathrm{mm}$ glass beads). Total bacteria were estimated from the number of copies of $16 \mathrm{~S}$ rRNA gene per nanogram of DNA. To quantify the ruminal bacteria $16 \mathrm{~S}$ rRNA gene, primers 520f and 799r2 were used as described previously (Edwards et al., 2007). Analysis was performed 
using the SYBR Premix Ex Taq kit (Applied Biosystems, Branchburg, NJ) on a StepOnePlus apparatus (Applied Biosystems) using absolute quantification. Capillary electrophoresis single-stranded conformation polymorphism was performed from the V3 region of the 16S rRNA gene as described by Michelland et al. (2009a) using an ABI Prism 3100 Genetic (Applied Biosystems).

Ruminal fluid added to MFS solution was diluted in an equal volume of PBS before protozoal enumeration under a microscope $(400 \times)$ in a Neubaeur enumeration chamber (Ranilla et al., 2007). The enzymatic activities of the ruminal contents were determined for 3 fractions (i.e., total, solid, and liquid). The extraction of the enzymes and the measurement of the activities of amylase, carboxymethyl cellulase (CMCase), and xylanase were done using the method described by Martin et al. (1993). The protein contents of the enzymatic preparations were determined by the technique of Bradford (1976), with bovine serum albumin as standard (Sigma, Saint Quentin Fallavier, France). The specific activities were expressed as $\mu \mathrm{mol} \cdot \mathrm{h}^{-1} \cdot \mathrm{mg}$ protein $^{-1}$ for the 3 fractions.

\section{Calculations and Statistical Analyses}

The measurements made at the end of EP 0 were used as covariables in all the statistical models used. The bacterial diversity was estimated using Simpson diversity index, which was calculated for each CE-SSCP profile using $-\log 10 \Sigma\left(\mathrm{a}_{\mathrm{i}}\right)^{2}$, with $\mathrm{a}_{\mathrm{i}}$ being the relative area under the ith peak (Rosenzweig, 1995). The time for adjustment after each dietary change allowed an approach of the medium-term effect of dietary changes and was not a studied factor.

All data were analyzed as repeated measures using a mixed model using the PASW Statistics 18 (SPSS, Inc.; IBM, 2011) software. Experimental period, time, $\operatorname{diet}(\mathbf{D}, 2$ levels: corn silage and hay), and fraction (F, 3 levels: total, solid, and liquid) were considered as fixed factors, and the cow and the covariable were considered as random factors. The factors EP, diet, and fraction and their second-order interactions were tested.

For the statistical analysis of the physicochemical and fermentation measurements, protozoa counts, quantification of total bacteria, and the diversity index, the model used was

$$
Y_{i j}=\mu+D_{i}+E P_{j}+(D \times E P)_{i j}+\varepsilon_{i j},
$$

where $\mathrm{Y}$ is the dependent variable, $\mu$ is the overall mean, $\mathrm{D}_{\mathrm{i}}$ is the diet effect, $\mathrm{EP}_{\mathrm{j}}$ is the EP effect, $(\mathrm{D} \times \mathrm{EP})_{\mathrm{ij}}$ is the interaction between diet and $\mathrm{EP}$, and $\varepsilon_{\mathrm{ij}}$ is the residual error.

For the statistical analyses of the enzymatic activi- ties, the fraction factor was added to the previous mixed model. The second statistical model was

$$
\begin{aligned}
& Y_{i j k}=\mu+D_{i}+E P_{j}+F_{k}+ \\
& (D \times E P)_{i j}+(D \times F)_{i k}+(E P \times F) j k+\varepsilon_{i j k},
\end{aligned}
$$

where $\mathrm{Y}$ is the dependent variable, $\mu$ is the overall mean, $D_{i}$ is the diet effect, $E_{j}$ is the EP effect, Fk is the fraction effect, $(\mathrm{D} \times \mathrm{EP})_{\mathrm{ij}}$ is the interaction between diet and $\mathrm{EP},(\mathrm{D} \times \mathrm{F})_{\mathrm{ik}}$ is the interaction between diet and fraction, $(\mathrm{EP} \times \mathrm{F})_{\mathrm{jk}}$ is the interaction between EP and fraction, and $\varepsilon_{\mathrm{ijk}}$ is the residual error.

When the effects of factors were significant at $P<$ 0.05 , the differences between the different levels of factors were tested by a Student's $t$ test with Bonferonni's correction. The differences were declared significant at $P<0.05$.

The bacterial community structure was analyzed using the Statfingerprints package (Michelland et al., 2009a) and the R software (R Development Core Team, 2009). The overall statistical analysis of bacterial community structure was performed with a multivariate ANOVA (MANOVA). The effects were declared significant at $P<0.05$. The analysis of similarity of the community structure (ANOSIM) was based on the calculation of pairwise Euclidean distance between the CESSCP profiles to obtain a distance matrix with 10,000 Monte Carlo permutations. The data of ANOSIM represented the degree of similarity of the community structure (ANOSIM-R). The effects were declared not significant at $P>0.05$ whatever the value of ANOSIM-R. If $P<0.05$, the value of ANOSIM-R indicated the degree of similarity between the groups: $R>0.75$ for well-separated groups, $0.50<R<0.75$ for separated but overlapping groups, $0.25<R<0.50$ for separated but strongly overlapping groups, and $R<0.25$ for nonseparated groups (Ramette, 2007).

\section{RESULTS}

\section{Intake and Physicochemical and Fermentation Measurements}

Throughout the trial, all food offered was eaten between each meal. The changes in $\mathrm{pH}$ with $\mathrm{EP}$ were different for the 2 diets (diet $\times$ EP interaction: $P=0.05$; Table 2 ). The switch to the corn silage-based diet at EP 3 resulted in a lower $\mathrm{pH}$ than at EP 1 and 2 (mean $\mathrm{pH}=6.27,6.28$, and 6.10 for the EP 1, 2 and 3, respectively, $P<0.05$; Figure 2 ). For the hay-based diet there was no difference in $\mathrm{pH}$ between the $3 \mathrm{EP}$ (mean $\mathrm{pH}=6.58,6.48$, and 6.55 for EP 1 , 2 , and 3 , respectively, $P=0.32$ ). The redox potential did not differ between the 2 diets or between the EP (Table 2). The VFA concentration was greater for the corn silage-based diet than for the hay-based diet $(P<0.001$; Table 2$)$; it fell 
Table 2. Physicochemical and fermentative measurements of the ruminal content from 6 cows fed 3 EP of a corn silage-based diet followed by a hay-based diet ${ }^{1}$

\begin{tabular}{|c|c|c|c|c|c|c|c|c|c|}
\hline \multirow[b]{2}{*}{ Item } & \multicolumn{2}{|c|}{ Diet } & \multicolumn{3}{|c|}{ EP } & \multirow[b]{2}{*}{ SEM $^{2}$} & \multicolumn{3}{|c|}{$P$-value } \\
\hline & Corn silage & Hay & 1 & 2 & 3 & & Diet & EP & Diet $\times$ EP \\
\hline $\mathrm{pH}$ & 6.22 & 6.54 & 6.42 & 6.38 & 6.32 & 0.35 & $<0.001$ & 0.21 & 0.050 \\
\hline VFA, $\mathrm{m} M$ & 86.0 & 66.2 & $90.1^{\mathrm{a}}$ & $79.5^{\mathrm{b}}$ & $58.7^{\mathrm{c}}$ & 3.4 & $<0.001$ & $<0.001$ & 0.086 \\
\hline Acetate, $\mathrm{m} M$ & 49.7 & 46.7 & 54.7 & 52.4 & 37.5 & 1.8 & 0.097 & 0.002 & 0.035 \\
\hline Propionate, $\mathrm{m} M$ & 18.9 & 11.9 & $20.3^{\mathrm{a}}$ & $14.2^{\mathrm{ab}}$ & $11.7^{\mathrm{b}}$ & 1.7 & $<0.001$ & 0.018 & 0.521 \\
\hline
\end{tabular}

${ }^{\mathrm{a}-\mathrm{c}}$ Within a row and within the EP category, means that do not have a common superscript differ; $P<0.05$.

${ }^{1} \mathrm{EP}=$ experimental period.

${ }^{2}$ The largest value of the SEM is reported. Means of 144 observations for the diet data, and for 96 observations for the EP data.

significantly between each EP $(P<0.001)$. For the acetate content the diet $\times \mathrm{EP}$ interaction was significant $(P<0.05$; Table 2). The acetate contents did not differ between EP 1 and 2 of the corn silage-based diet (mean acetate content $=$ 51.5 and $53.8 \mathrm{mM}$ for EP 1 and 2, respectively; Figure 3). Experimental period 3 of the corn silage-based diet had a lower acetate concentration than EP 2 (mean acetate $=53.8$ and $43.6 \mathrm{~m} M$ for the EP 2 and 3, respectively, $P<0.05$ ) but was not different from that of EP 1 . For the hay-based diet, the acetate concentrations did not differ between EP 1 and 2, which were significantly greater than that of EP 3 (mean acetate $=57.8,50.8$, and $31.4 \mathrm{~m} M$ for EP 1, 2, and 3 , respectively, $P<0.001)$. For the propionate and butyrate concentrations the diet $\times$ EP interaction was not significant. Concentrations of these 2 VFA were greater for the corn silage-based diet than for the hay-based $\operatorname{diet}(P<0.001$; Table 2). The successive EP led to lower and lower values of propionate and butyrate, with significant differences between EP 1 and $3(P<0.05)$.

The ammonia concentration changed with the EP differently according to the nature of the diet (diet $\times$ EP interaction: $P<0.001$; Table 2). Thus, the successive EP of the corn silage-based diet led to an increase in ammonia, with

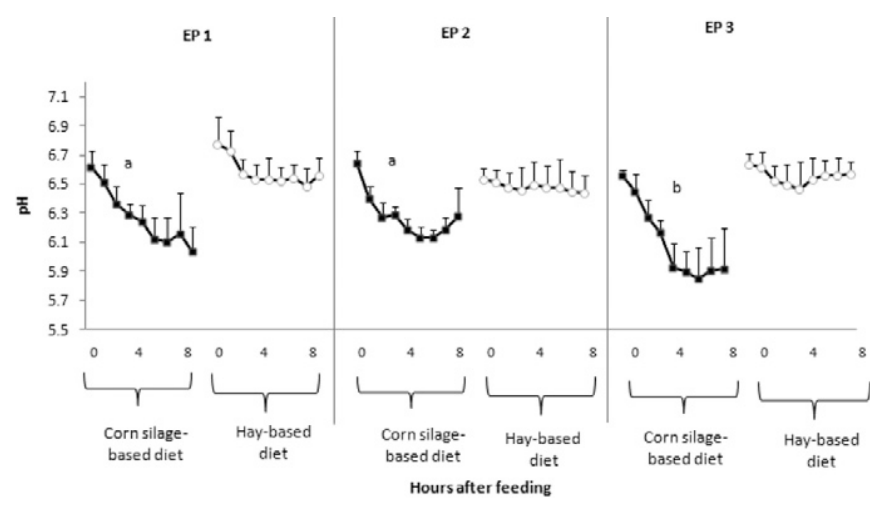

Figure 2. Ruminal $\mathrm{pH}$ measured after the morning feed and hourly for $8 \mathrm{~h}$ on the last day of the corn silage-based (squares) and hay-based diets (circles) from 6 cows fed 3 experimental periods (EP) of a corn silage-based diet followed by a hay-based $\operatorname{diet}(\mathrm{EP} \times \operatorname{diet} P$-value $=0.050)$. Bars $=$ cow SD. ${ }^{\mathrm{a}-\mathrm{c}}$ Overall means values across time that do not have a common superscript differ $(P<0.05)$ within the corn silage-based diet. a significantly greater value during EP 3 (mean ammonia = 59.4, 78.9, and 212.6 mg/L for EP 1, 2, and 3, respectively, $P<0.05$; Figure 4). Experimental period 2 of the hay-based diet led to a greater ammonia concentration than during EP 1 and 3 , for which it did not differ (mean ammonia $=56.0$, 111.0, and $38.9 \mathrm{mg} / \mathrm{L}$ for EP 1, 2, and 3, respectively, $P<$ $0.05)$.

The lactate concentration was typically under the detection threshold of the kit used for measurement. As a result, the data were not analyzed statistically (data not shown).

\section{Microbiota}

Quantification of the Bacterial Community. The effects of the diet and the diet $\times$ EP interaction were not significant for the total quantity of bacteria (Table 3), which fell between EP 1 and $2(P=0.020)$ and then increased slightly for EP 3, whose value was not different from the other 2 .

Structure of the Bacterial Community. The global

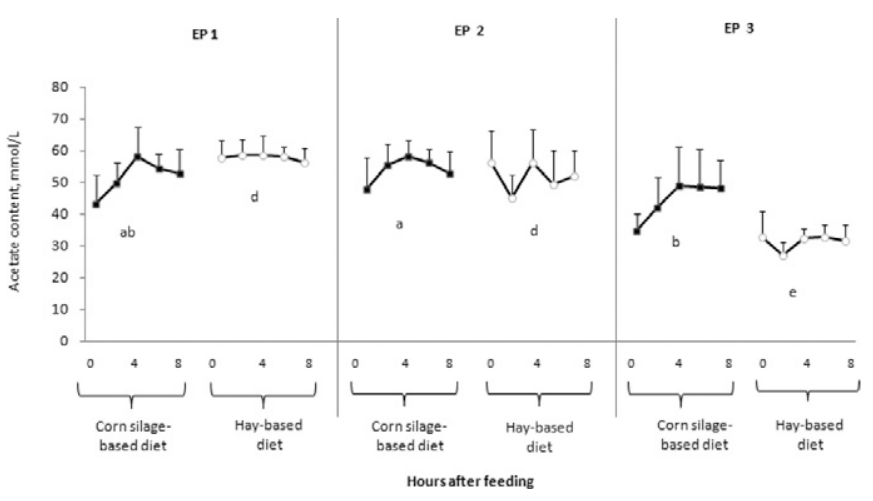

Figure 3. Ruminal acetate concentration measured after the morning feed and every hour for $8 \mathrm{~h}$ on the last day of the corn silage-based (squares) and hay-based diets (circles) from 6 cows fed 3 experimental periods (EP) of a corn silage-based diet followed by a hay-based diet $(\mathrm{EP} \times \operatorname{diet} P$-value $=$ $0.035)$. Bars $=$ cow SD. ${ }^{a-c}$ Overall means values across time that do not have a common superscript differ $(P<0.05)$ within the corn silage-based diet. ${ }^{\mathrm{d}-\mathrm{f}}$ Overall means values across time that do not have a common superscript differ $(P<0.05)$ within the hay-based diet. 
Table 3. Ruminal total bacterial (cells $\times 105 / \mathrm{ng}$ DNA) and protozoa counts (cells $\times 104 / \mathrm{mL}$ ) from 6 cows fed 3 EP of a corn silage-based diet followed by a hay-based diet ${ }^{1}$

\begin{tabular}{|c|c|c|c|c|c|c|c|c|c|}
\hline \multirow[b]{2}{*}{ Item } & \multicolumn{2}{|c|}{ Diet } & \multicolumn{3}{|c|}{ EP } & \multirow[b]{2}{*}{ SEM $^{2}$} & \multicolumn{3}{|c|}{$P$-value } \\
\hline & Corn silage & Hay & 1 & 2 & 3 & & Diet & EP & Diet $\times$ EP \\
\hline Total bacteria & 1.83 & 2.61 & $3.11^{\mathrm{a}}$ & $1.31^{\mathrm{b}}$ & $2.23^{\mathrm{ab}}$ & 0.587 & 0.144 & 0.020 & 0.113 \\
\hline Simpson diversity index & 6.77 & 7.37 & 6.68 & 6.99 & 7.53 & 0.290 & 0.082 & 0.084 & 0.036 \\
\hline Entodinium $<100 \mu \mathrm{m}$ & 67.8 & 13.7 & 22.9 & 48.7 & 50.7 & 8.90 & $<0.001$ & $<0.01$ & 0.035 \\
\hline Entodinium $>100 \mu \mathrm{m}$ & 182 & 0.06 & 0.18 & 0.56 & 209 & 0.43 & $<0.001$ & $<0.01$ & $<0.01$ \\
\hline Isotricha & 0.27 & 0.08 & 0.04 & 0.67 & 0.42 & 0.07 & $<0.01$ & $<0.001$ & $<0.001$ \\
\hline Dasytricha & 0.24 & 319 & 149 & 171 & 184 & 0.48 & $<0.001$ & 0.692 & 0.313 \\
\hline Total protozoa & 70.1 & 17.1 & 24.6 & 51.0 & 55.2 & 8.90 & $<0.001$ & $<0.01$ & 0.026 \\
\hline
\end{tabular}

${ }^{\mathrm{a}-\mathrm{c} W i t h i n}$ a row and within the EP category, means that do not have a common superscript differ; $P<0.05$.

${ }^{1} \mathrm{EP}=$ experimental period.

${ }^{2}$ Largest value of the SEM is reported. Means of 144 observations for the Diet data, and for 96 observations for the EP data.

approach to the CE-SSCP profiles for studying the structure of the microbial community showed a diet $\times$ EP interaction (MANOVA, $P=0.002$; data not shown). For the corn silage-based diet, the CE-SSCP profiles did not differ for the $3 \mathrm{EP}$ of the treatment ( $P$-value of ANOSIM$\mathrm{R}>0.05$; Table 4). The CE-SSCP profiles obtained for EP 1 and 3 of the hay-based diet show large differences in the structures of the bacterial community (ANOSIM$\mathrm{R}=0.46$ with $P=0.03$; Table 4). Between EP 2 and 3 of the hay-based diet, the differences in the CE-SSCP profiles were very large and significant (ANOSIM-R = 0.98 with $P=0.01$; Table 4).

Diversity Index of the Bacterial Community. The estimation of Simpson diversity index showed different changes between the EP for the 2 diets $(P=0.036$; Table $3)$. It fell between EP 1 and 2 of the corn silage-based diet, although not significantly, and increased significantly $(P=0.007)$ between EP 2 and 3 (Figure 5). For this diet, the diversity indices of EP 1 and 3 were the same. The index increased significantly between EP 1

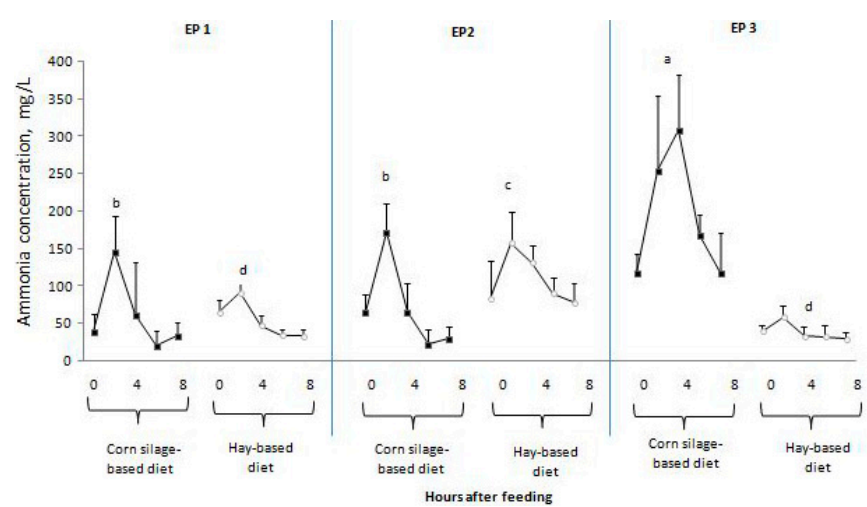

Figure 4. Ruminal ammonia concentrations measured after the morning feed and hourly for $8 \mathrm{~h}$ on the last day of the corn silage-based (squares) and hay-based diets (circles) from 6 cows fed 3 experimental periods (EP) of a corn silage-based diet followed by a hay-based $\operatorname{diet}(\mathrm{EP} \times \operatorname{diet} P$-value $<$ 0.001). Bars $=$ cow SD. ${ }^{a, b}$ Overall means values across time that do not have a common superscript differ $(P<0.05)$ within the corn silage-based diet.

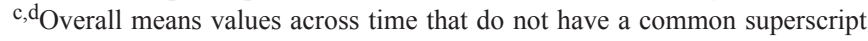
differ $(P<0.05)$ within the hay-based diet. and 2 of the hay-based diet $(P=0.018)$, whereas EP 3 of the hay-based diet was the same as for the first 2 .

Counting Protozoa. Counts of ciliated protozoa in the ruminal contents showed a diet $\times$ EP interaction for total protozoa $(P=0.026)$, the genera Entodinium (below and above $100 \mu \mathrm{m} ; P=0.035$ and $<0.01$, respectively), and Isotricha $(P<0.001$; Table 3$)$. The total number of protozoa increased significantly between EP 1 and 3 of the corn silage-based diet $(P=0.022$; Figure 6A). For the hay-based diet the total number of protozoa for EP 2 was more than that of EP $1(P=0.002)$, whereas that of EP 3 was the same as the other 2 EP. The number of Entodinium below $100 \mu \mathrm{m}$ was greater for EP 2 and 3 of the corn silage-based diet than for EP $1(P=0.03$; Figure $6 \mathrm{~B})$. For the hay-based diet, the number of Entodinium below $100 \mu \mathrm{m}$ also increased, but the only significant difference was between EP 1 and $3(P=0.025)$. The count of Entodinium above $100 \mu \mathrm{m}$ was greater for EP 3 of the corn silage-based diet than for EP $1(P=0.022$; Figure $6 \mathrm{C})$. For the hay-based diet there was no difference in the counts of Entodinium above $100 \mu \mathrm{m}$ among the 3 EP. The number of Isotricha increased between each EP of the corn silage-based diet $(P<0.01$; Figure $6 \mathrm{D})$, but there was no difference for the hay-based diet. The EP effect and the diet $\times$ EP interaction were not significant for counts of Dasytricha. The count of the genus Dasytricha was greater for the hay-based diet than for the silage-based diet $(P<0.001$; Table 3$)$.

Table 4. Similarity analysis of the structure of the ruminal bacterial community from 6 cows fed 3 EP of a corn silage-based diet followed by a hay-based diet ${ }^{1}$

\begin{tabular}{lcccc}
\hline \hline & \multicolumn{4}{c}{ Diet } \\
\cline { 2 - 5 } Pairwise & \multicolumn{2}{c}{ Corn silage } & \multicolumn{2}{c}{ Hay } \\
\cline { 2 - 5 } comparison & ANOSIM-R & $P$-value & ANOSIM-R & $P$-value \\
\hline EP 1 vs. 2 & 0 & 0.56 & 0.159 & 0.23 \\
EP 1 vs. 3 & 0.01 & 0.58 & 0.464 & 0.03 \\
EP 2 vs. 3 & 0.05 & 0.28 & 0.979 & 0.01 \\
\hline
\end{tabular}

${ }^{1} \mathrm{EP}=$ experimental period. ANOSIM-R $=$ degree of similarity of the community structure by analysis of similarity of the profiles. 
Table 5. Amylase, carboxymethyl cellulose, and xylanase specific activities of the ruminal content from 6 cows fed $3 \mathrm{EP}$ of a corn silage-based diet followed by a hay-based diet according to the ruminal fraction ${ }^{1}$

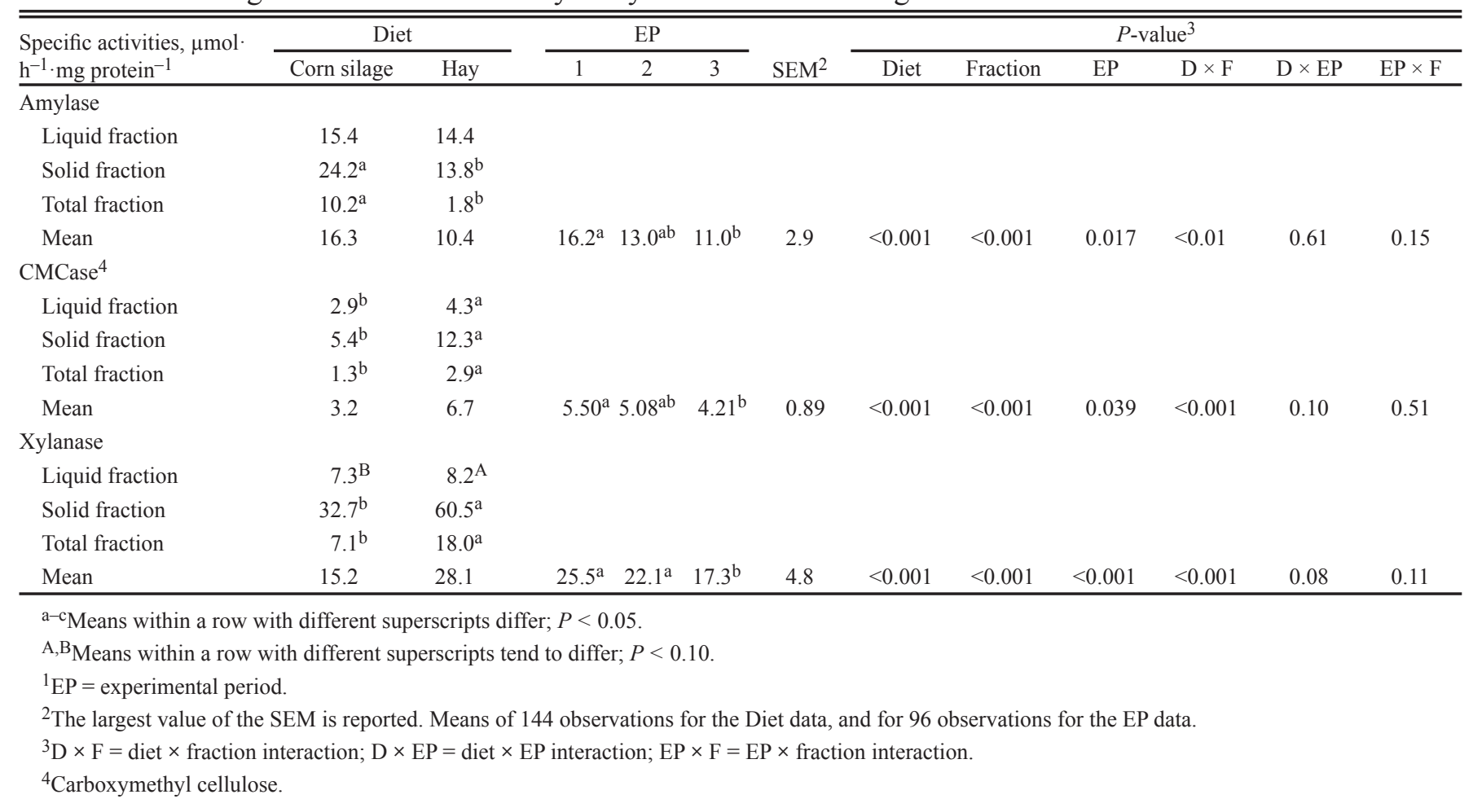

\section{Specific Enzymatic Activities}

The specific amylase and CMCase activities fell during the course of the $3 \mathrm{EP}$ with significant differences between $(P=0.017)$ EP 1 and 3 (Table 5). The xylanase activity also fell between the $3 \mathrm{EP}$, with a significantly lower $(P<0.001)$ activity for EP 3 . The diet $\times$ fraction interaction was significant for the 3 activities $(P<0.01)$. The specific amylase activity was significantly higher $(P<0.01)$ in the solid and total fractions for the corn silage-based diet than for the hay-based diet (Table 5). The specific CMCase activity was higher $(P<0.001)$ in the 3 fractions for the hay-based diet than for the corn silage-based diet, with a greater difference between the diets in the solid fraction. The specific xylanase activity was greater $(P<0.001)$ in the solid and total fractions for the hay-based diet than for the corn silage-based diet. No diet $\times \mathrm{EP}$ or $\mathrm{EP} \times$ fraction interaction was significant for the specific amylase, CMCase, or xylanase activities (Table 5).

\section{DISCUSSION}

A change of diet led to a disturbance to the ruminal ecosystem, whatever the change applied (i.e., corn silage- to hay-based diet or vice versa). Dietary disturbance is a powerful tool to better understand the functioning of the ruminal ecosystem. Indeed, the response pattern to the perturbation [resistant (i.e., remaining unchanged) or altered, with or without the capacity to re- turn to the initial state] gives some insight into engineering the ruminal ecosystem toward an optimal outcome for the host, especially the digestive efficiency. Very little published work treats the repetition of disturbances applied to a digestive ecosystem. Our work has the advantage of approaching the ruminal ecosystem under particular conditions of repeated disturbance more completely than was previously mentioned in the literature, with a study of microorganisms (bacteria and protozoa), their behavior (enzymatic activity), and the level of their activity (physicochemical and fermentation).

Experimental period 1 of the corn silage-based diet led to ruminal measurements typically observed for a diet based on corn silage, which is not particularly acidogenic, as confirmed by the fairly high $\mathrm{pH}$ values. In our study, the intake of diet was not affected by EP, whereas a short-term decrease in intake has been reported after an acidogenic challenge (Blanch et al., 2009). When the corn silage-based diet was repeated, the ruminal $\mathrm{pH}$ fell and reached values under 6 for EP 3, as previously demonstrated by Dohme et al. (2008). The hay-based diet resulted in similar ruminal $\mathrm{pH}$ values for the $3 \mathrm{EP}$, despite the different previous $\mathrm{pH}$ levels (i.e., $\mathrm{pH}$ at the end of corn silage-based diet periods). The previous disturbance, as well as the number of the previous disturbances, seemed not to affect the ruminal $\mathrm{pH}$, indicating for $\mathrm{pH}$ a capacity of the ecosystem to return to equilibrium. The redox potential value did not differ between the diets or among the EP. Julien et al. (2010) showed decreasing values of redox potential for diets 


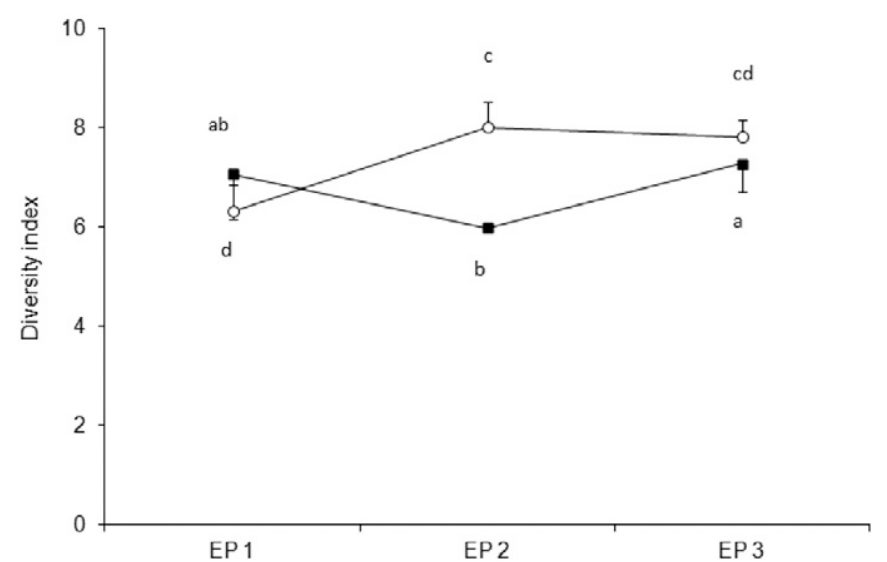

Figure 5. Simpson diversity index of the ruminal bacterial communities estimated from each individual capillary electrophoresis single-strand conformation polymorphism (CE-SSCP) profiles on the last day of the corn silage-based (squares) and hay-based diets (circles) from 6 cows fed 3 experimental periods (EP) of a corn silage-based diet followed by a hay-based $\operatorname{diet}(\mathrm{EP} \times \operatorname{diet} P$-value $=0.036)$. Bars $=$ cow SD. ${ }^{\mathrm{a}, \mathrm{b}}$ Index values that do not have a common superscript differ $(P<0.05)$ within the corn silage-based diet. ${ }^{\mathrm{c}, \mathrm{d}}$ Index values that do not have a common superscript differ $(P<0.05)$ within the hay-based diet.

with increasing fiber content. It has been reported that this measurement needs a long time for adaptation to the diet before stabilizing (Monteils et al., 2009, 2011). The brief length of the EP applied in our study between the disturbances could explain the absence of differences of redox potential between the 2 diets and among the EP. In our study, precautions were taken to consider differences of digesta flows for both diets by different times for adjustment before sampling. These precautions could have resulted in confusion of the effects of the diet and the time for adjustment.

The total VFA, propionate, and butyrate concentrations decreased progressively with EP. The repetition of the disturbances did not allow the ruminal ecosystem to maintain its fermentation level. The negative effect of the repetition of the disturbances was more marked for the hay-based diet, with also a very large decrease in the acetate concentration. The decreases of amylase, CMCase, and xylanase enzymatic activities corroborated these data. The enzymatic activities were observed for whole microorganisms (bacteria, protozoa, and fungi) because the measure of the enzymatic activities showed the total activities without distinction. The repeated disturbances seemed to involve an alteration in the capacity of the ruminal microorganisms to ferment substrate; however, the ammonia concentration increased with EP for the corn silage-based diet. Considering all the fermentative data, this increase in ammonia could be attributed to decreased utilization by microorganisms rather than increased production. As noted previously, lactic acid concentration was typically under the detection threshold throughout the study. Thus, the repeated disturbances seemed to have no effect on this variable.
In our study the total quantity of bacteria fell together with the repeated disturbances and the decrease in VFA. This decrease could be the result of selection for species resistant to the applied disturbances. This idea might help to explain the decreases in enzymatic activity by modification of microorganisms and decreased utilization of ammonia for multiplication. The Simpson diversity index is an estimation of bacterial diversity from abundance and number of operational taxonomic units (OTU; Rosenzweig, 1995). A change in this index indicated a change in the bacterial community (i.e., relative abundance of OTU or number of OTU or both). The succession of diet perturbations led to either modification of the Simpson diversity index or the bacterial community structure depending of the dietary change. These changes might be attributed to the appearance or disappearance of OTU (as observed for the hay-based diet) or to changes in the relative abundance of certain OTU (as observed for the corn silagebased diet). All these changes in the bacterial community were counterproductive to ruminal function according to the fermentation measurements evaluated. In our study, the alteration in ruminal function could be linked to the decrease of abundance of certain OTU, probably the OTU that had great activity according to the strong decrease of fermentative measurements and enzymatic activities. Other explanations could be that the species that were resistant to the disturbances had altered fermentative capacities or that the disturbances involved an increase of the digestive flow and turnover, which implied a lesser multiplication of bacteria and decreased fermentative activity. In the present study, the bacteria number was estimated from the number of copies of the $16 \mathrm{~S}$ rRNA gene. As a result, the distinction between live and dead bacteria could not be made, which could cause a misinterpretation of the bacteria density. The structure of the bacteria community was studied with the CE-SSCP method, which could be insufficiently precise to display the low differences observed for the corn silagebased diet.

The repetition of the corn silage-based diet involved an increase of the total protozoa, especially the populations of Entodinium below and above $100 \mu \mathrm{m}$ and Isotricha. For the hay-based diet, the EP resulted in weak increases in the total protozoa and the Entodinium below $100 \mu \mathrm{m}$. The protozoa seemed to be more resistant to the applied disturbances than the bacteria, and multiplication still occurred, especially for the corn silage-based diet. Dasytricha also resisted the disturbances because of its content, which was similar throughout the study, but the absence of an increase with the disturbances resulted in supposed lesser appropriate conditions for this genus than for the others. The protozoa counts have been shown to be greater when animals were fed a diet richer in starch rather than in fiber (Ivan et al., 2000). The development of the protozoal population has been shown 

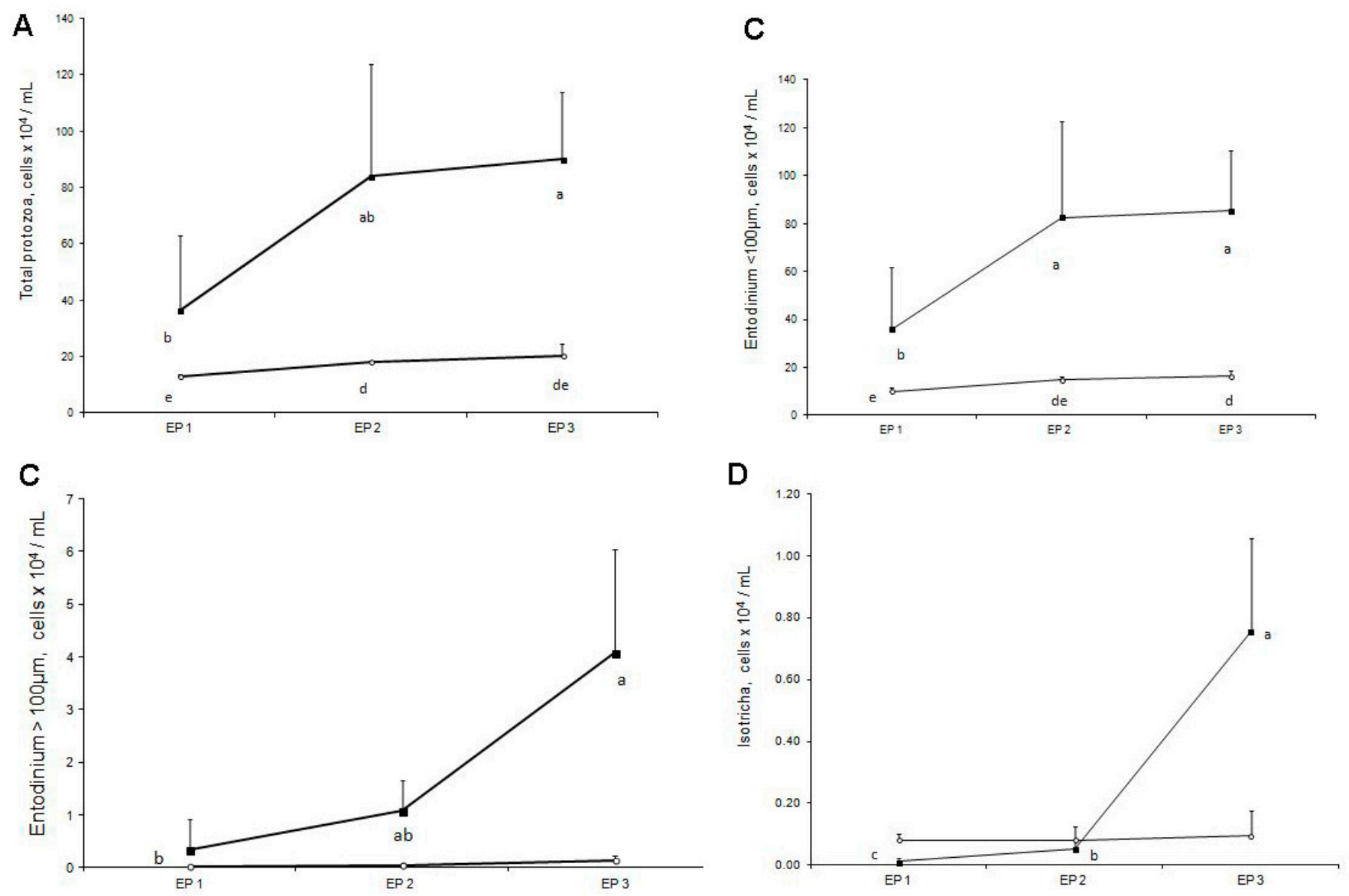

Figure 6. (A) Total protozoa, (B) Entodinium below $100 \mu \mathrm{m}$, (C) Entodinium above $100 \mu \mathrm{m}$, and (D) Isotricha counts on the last day of the corn silagebased (squares) and hay-based diets (circles) from 6 cows fed 3 experimental periods (EP) of a corn silage-based diet followed by a hay-based diet (EP $\times$ diet $P$-value $=0.026$ and 0.035 , respectively, for total protozoal and Entodinium below $100 \mu \mathrm{m}$ counts and $<0.01$ and $<0.001$, respectively, for Entodinium above 100 $\mu \mathrm{m}$ and Isotricha counts). Bars = cow SD. ${ }^{\mathrm{a}-\mathrm{c}}$ Counts that do not have a common superscript differ $(P<0.05)$ within the corn silage-based diet. ${ }^{\mathrm{d}, \mathrm{e}}$ Counts that do not have a common superscript differ $(P<0.05)$ within the hay-based diet.

to accentuate the bacteria-protozoa competition for the use of substrates, notably starch (Rowe et al., 1985), and to limit the development of amylolytic bacteria (Fonty et al., 1995). Entodinium and Dasytricha have been reported to degrade starch (Williams and Coleman, 1992), but to a lesser extent than bacteria (Fonty et al., 1995). For the hay-based diet, the bacteria-protozoa competition can be assumed to be weaker. Nevertheless, the amylase activity fell in the same way as for the corn silagebased diet. In our study, the measured amylase activity corresponded to the total activity of the microorganisms and did not allow distinguishing the part attributable to bacteria. The development of cellulolytic bacteria was shown to be favored by protozoa (Fonty et al., 1995); however, the fall in CMCase activity with the increase in the number of protozoa did not support this result. It seemed in our study that the decrease of bacterial density by a repetition of disturbances allowed an increase of the protozoan population. Nonetheless, the increase of protozoal density seemed not to be sufficient to avoid an alteration in ruminal function.

In conclusion, dietary changes involved an altera- tion of the ruminal function with decreases in ruminal fermentative end products and major enzymatic activities and strong changes in the balance within the ruminal ecosystem. An accentuation of these alterations and changes was observed with the repetition of dietary changes. A logical consequence should be decreased performance, but this would need to be evaluated in additional experiments and over a longer term with growing or lactating animals. A more detailed study of the bacterial species could help us to better understand the changes in the observed functions.

\section{LITERATURE CITED}

Allison, S. D., and J. B. H. Martiny. 2008. Resistance, resilience, and redundancy in microbial communities. Proc. Natl. Acad. Sci. U. S. A. 105(Suppl. 1):11512-11519.

Blanch, M., S. Calsamiglia, N. DiLorenzo, A. DiCostanzo, S. Muetzel, and R. J. Wallace. 2009. Physiological changes in rumen fermentation during acidosis induction and its control using a multivalent polyclonal antibody preparation in heifers. J. Anim. Sci. 87:1722-1730.

Bradford, M. M. 1976. A rapid and sensitive method for the quantitation of microgram quantities of protein utilizing the principle of 
protein-dye binding. Anal. Biochem. 72:248-254.

Dohme, F., T. J. DeVries, and K. A. Beauchemin. 2008. Repeated ruminal acidosis challenges in lactating dairy cows at high and low risk for developing acidosis: Ruminal pH. J. Dairy Sci. 91:3554-3567.

Edwards, J. E., S. A. Huws, E. J. Kim, and A. H. Kingston-Smith. 2007. Characterization of the dynamics of initial bacterial colonization of nonconserved forage in the bovine rumen. FEMS Microbiol. Ecol. 62:323-335.

Faichney, G. J. 1995. Transit des digesta dans le tube digestif des ruminants. Pages 431-464 in Nutrition des ruminants domestiques. Ingestion et digestion. R. Jarrige, Y. Ruckebusch, C. Demarquilly, M. H. Farce, and M. Journet, eds., Paris, France.

Fonty, G., J. P. Jouany, E. Forano, and P. Gouet. 1995. L'écosystème microbien du réticulo-rumen. Pages 299-348 in Nutrition des ruminants domestiques. Ingestion et digestion. R. Jarrige, Y. Ruckebusch, C. Demarquilly, M. H. Farce, and M. Journet, ed. INRA editions, Paris, France.

France. 1988. Arrêté du 18 avril 1988 fixant les conditions d'attribution de l'autorisation d'expérimenter. J. Off. République Fr., 27 April:5608-5610.

Goad, D. W., C. L. Goad, and T. G. Nagaraja. 1998. Ruminal microbial and fermentative changes associated with experimentally induced subacute acidosis in steers. J. Anim. Sci. 79:234-241.

IBM. 2011. SPSS Statistics 20 Core System, User's Guide, New York, NY.

Ivan, M., L. Neill, R. Forster, R. Alimon, L. M. Rode, and T. Entz. 2000. Effects of Isotricha, Dasytricha, Entodinium, and total fauna on ruminal fermentation and duodenal flow in wethers fed different diets. J. Dairy Sci. 83:776-787.

Jarrige R., 1989. Ruminant Nutrition: Recommended Allowances and Feed Tables. John Libbey, London, UK.

Julien, C., J. P. Marden, C. Bonnefont, R. Moncoulon, E. Auclair, V. Monteils, and C. Bayourthe. 2010. Effects of varying proportions of concentrates on ruminal reducing power and bacterial community structure in dry dairy cows fed hay-based diets. Animal 4:1641-1646.

Krom, M. D. 1980. Spectrophotometric determination of ammonia. The Analyst 105:305-316.

Marden, J.-P., C. Bayourthe, F. Enjalbert, and R. Moncoulon. 2005. A new device for measuring kinetics of ruminal $\mathrm{pH}$ and redox potential in dairy cattle. J. Dairy Sci. 88:277-281.

Martin, C., B. Michalet-Doreau, G. Fonty, and A. Williams. 1993. Postprandial variations in the activity of polysaccharide-degrading enzymes of fluid- and particle-associated ruminal microbial populations. Curr. Microbiol. 27:223-228.

Michelland, R. J., S. Dejean, S. Combes, L. Fortun-Lamothe, and L. Cauquil. 2009a. StatFingerprints: A friendly graphical interface program for processing and analysis of microbial fingerprint profiles. Mol. Ecol. Res. 9:1359-1363.

Michelland, R., V. Monteils, S. Combes, L. Cauquil, T. Gidenne, and
L. Fortun-Lamothe. 2011. Changes over time in the bacterial communities associated with fluid and food particles and the ruminal parameters in the bovine rumen before and after a dietary change. Can. J. Microbiol. 57:629-637.

Michelland, R., V. Monteils, A. Zened, S. Combes, L. Cauquil, T. Gidenne, J. Hamelin, and L. Fortun-Lamothe. 2009b. Spatial and temporal variations of the bacterial community in the bovine digestive tract. J. Appl. Microbiol. 107:1642-1650.

Monteils, V., M. Rey, L. Cauquil, A. Troegeler-Meynadier, M. Silberberg, and S. Combes. 2011. Random changes in the heifer rumen in bacterial community structure, physico-chemical and fermentation parameters, and in vitro fibre degradation. Livestock Sci. 141:104-112.

Monteils, V., M. Rey, and T. Gidenne. 2009. Mid to long term stability of ruminal physicochemistry in dairy cows fed a fibre- or a starch-based diet. Pages 284-285 in XIth Int. Symp. on Rumin. Physiol., Clermont-Ferrand, France.

Nordstrom, D. K. 1977. Thermochemical redox equilibria of Zo Bell's solution. Geochim. Cosmochim. Acta. 41:1835-1841.

Playne, M. J. 1985. Determination of ethanol, volatile fatty acids, lactic acid and succinic acid in fermentation liquids by gas chromatography. J. Sci. Food Agric. 36:638-644.

Privé, F., S. Combes, L. Cauquil, Y. Farizon, F. Enjalbert, and A. Troegeler-Meynadier. 2010. Temperature and duration of heating of sunflower oil affect ruminal biohydrogenation of linoleic acid in vitro. J. Dairy Sci. 93:711-722.

R Development Core Team. 2009. R: A Language and Environment for Statistical Computing. R Found. Stat. Comput., Vienna.

Ramette, A. 2007. Multivariate analyses in microbial ecology. FEMS Microbiol. Ecol. 62:142-160.

Ranilla, M. J., J. P. Jouany, and D. P. Morgavi. 2007. Methane production and substrate degradation by rumen microbial communities containing single protozoal species in vitro. Lett. Appl. Microbiol. 45:675-680.

Rosenzweig, M. L., ed. 1995. Species Diversity in Space and Time. Cambridge Univ. Press, Cambridge, UK.

Rowe, J. B., A. Davies, and A. W. J. Broome. 1985. Quantitative effects of defaunation on rumen fermentation and digestion in sheep. Br. J. Nutr. 54:105-119.

Tajima, K., S. Arai, K. Ogata, T. Nagamine, H. Matsui, M. Nakamura, R. I. Amanov, and Y. Benno. 2000. Rumen bacterial community transition during adaptation to high-grain diet. Anaerobe 6:273-284.

Tajima, K., T. Nagamine, H. Matsui, M. Nakamura, and R. I. Aminov. 2001. Phylogenetic analysis of archaeal 16S rRNA libraries from the rumen suggests the existence of a novel group of archaea not associated with known methanogens. FEMS Microbiol. Lett. 200:67-72.

Williams, A. G., and G. S. Coleman, eds. 1992. The Rumen Protozoa. Springer-Verlag, New York. 
References

This article cites 24 articles, 2 of which you can access for free at: http://www.journalofanimalscience.org/content/90/12/4431\#BIBL 